\title{
Concluding Remarks: Personal Reflections
}

\section{Michael Asch University of Victoria}

I would like to thank the authors for their valuable contributions to this special issue, as well as Sylvie Poirier and Clint Westman for inviting me to write these concluding remarks. The articles, taken together, offer much valuable insight on the troubled state of relations between Canada and those Indigenous Peoples, who are in the process of or have completed negotiations on what are known as land claims, both in the regions discussed here, and in Canada more generally. In fine, the contributions show that one party, Canada, uses its power to ensure that the results conform to its objectives and not those of the less powerful Indigenous parties. That is, when looked at from governments' central objectives, so-called negotiations are largely a sham. For, rhetoric notwithstanding, final agreements must always conform to their preconditions: in this, the rule is that might makes right.

In this regard, I am sorry to say that things have not changed significantly since the 1970s - an assertion I can make based on my first-hand experience working for the Dene-Métis Negotiations Secretariat in the Northwest Territories, largely as research director, for about a decade beginning in 1978 and, through that, having a direct engagement with the matters I discuss in these papers. ${ }^{1}$

It is a realisation that leads me here to consider what it tells us about Canada - that after all that has transpired, it remains where it was 40 years ago - and then ask what it suggests about how we proceed as anthropologists engaged in the negotiation process. I will begin by enumerating the four preconditions the state imposes on Indigenous Peoples in order to reach an agreement. I will then turn to an assessment of where, based on these findings, we might go from here.

\section{Cede and Surrender}

Canada's first non-negotiable demand is that all final agreements include language in which the Indigenous party stipulates that any political (and other) rights they possess as nations by virtue of the fact that they were here before colonisation are subordinated to the rule of Canada. In exchange, agreements guarantee them specified rights, but these are never sufficiently robust to stop Canada from overriding them when governments perceive themselves to be acting in the national (and/or provincial) interest.

This demand runs counter to the position long held by virtually all Indigenous parties that the goal of negotiations is the creation of a treaty partnership whereby the parties work cooperatively for the benefit of all. Often glossed as a nation-to-nation relationship, this is a phrase now frequently mouthed but certainly not honoured by Canada's political leadership, regardless of party. Still, for the most part, Indigenous parties negotiate in the belief, as with the Regroupement Petapan discussed in the essay by Sukrän Tipi and Hélène Boivin, that their agreement will be "based on recognition of rights rather than their extinction and/or abandonment."'

However, the truth is that, to date, this has never been the case. All final agreements contain language subordinating Indigenous polities to the rule of Canada. And while the signatures on the page may indicate that such agreements were "voluntary," in point of fact, by and large, Indigenous parties do not sign up except when coerced to do so, often from fears of imminent unwanted development and/or encroachment through overlap. In fact, in my mind, the only thing that has changed in 40 years is the language the federal government requires to signal agreement to extinguish. In the 1970s, as Colin Scott points out in his essay, the phrase was "cede and surrender." Now, perhaps as a way to ameliorate the cognised impact symbolically, less stark language is used language that entails the subordination of Indigenous authority in substantive areas of jurisdiction rather than its extinguishment.

\section{Standing to Negotiate}

The second non-negotiable demand is that the Indigenous party prove to the federal government's satisfaction that it has the standing to negotiate. To gain it, as the Tipi and Boivin eloquently demonstrate, federal (and provincial) negotiators insist Indigenous parties 
undertake extensive and costly studies detailing the history of their land use and occupancy in the territories potentially under claim. At the same time, Canada (and provinces) presumes, without a factual basis, that its standing to negotiate is self-evident and that it has such standing without proof. However, such standing is only grounded in counterfactual colonial-era beliefs such as the proposition that Canada was legally unoccupied at the time of European settlement, notwithstanding the presence of Indigenous Peoples here, living on the land.

Adding to this absurdity is the federal government's unilateral decision that it has the authority to make the final determination of the strength of a "claim" on its own rather than through an independent third-party process. This determination only proves that rather than to seek fairness, the state uses its power to impose rules that benefit itself. The question, then, is why Canada is permitted to get away with this.

Finally, while federal policy now recognises that more than one community may have valid claims respecting the same lands, it still evaluates them. In this regard, the federal government's so-called gold standard is met whenever a claimant group can demonstrate through land use and occupancy studies that it has exercised and still exercises exclusive, full control of the land in question. This position, as I understand it, is derived not from recourse to any Indigenous legal precept but rather from the unilateral imposition of the common law proviso that exclusion of others from a territory provides unequivocal proof of ownership. Consequently, Indigenous claimants often shape their studies to foreground evidence that minimises the land use of Indigenous persons, even close relatives, not included in that group. Thus, they create competition among groups as each seeks to demonstrate its claim as the strongest; and this frequently generates long-term animosity and antagonism among people who in other circumstances may well be allies and friends.

These requirements constitute prima facie a case of power, not principle, guiding the terms for negotiations another instance of might makes right. Yet, due to the power differential, negotiations never begin until the Indigenous party agrees to them.

\section{The "Problem" of "Overlap"}

This leads me to the third precondition discussed in this issue's articles. It is that agreements must result in dividing people into two oppositional groups: one that includes beneficiaries associated with a single, bounded territory, and the other of non-beneficiaries who stand outside even when they may be close relatives and/or share the same territories. As is well known, the imaginary of living in state-like socio-political isolates runs counter to the ways in which Indigenous people (and many others) organise themselves on the land. In particular, as has been explained repeatedly to federal negotiators since the 1970s and is reiterated in very strong terms in these essays, Indigenous Peoples generally organise themselves through webs of relationship among one another and with the landscape itself. Such relational webs move beyond any specific territorial boundary to create networks, not sharply bounded groups. Speaking generally, to achieve a settlement requires that a community accept a political frame that cuts links between peoples and lands that are interconnected and thus violates core principles and norms of Indigenous polity.

The disjuncture between the government's ideal of a settlement and the reality of Indigenous practices is often represented by the term overlap. This is a word that, even in its most neutral connotation, favours the Canadian state's perspective, for it conjures the image of either one primary community with the other represented as an overlay or, as with a Venn diagram, a series of overlays that imply multiple communities independently using the same land rather than sharing it.

More crucially, when viewed from within the context of negotiations, it is in fact a misnomer, for overlap in this mindset is only a descriptor of a problem that requires a solution rather than a fact. Here is what I mean: from Canada's point of view, each settlement ideally consists of self-contained territory with a single group of beneficiaries. That is, there is no overlap. This means that, in the first instance, the objective of claimant groups, as discussed above, is to ensure that there is no so-called overlap even when it means excluding certain people from benefits.

Another way to "solve" this problem, as discussed by Tipi and Boivin, is for governments to declare that once one party (in this case, the James Bay Cree through the James Bay and Northern Quebec Agreement of 1975) has a settlement in which the ancestral rights of that party have been extinguished in that territory, they will not recognise the right of any other group (in this case, the Naskapi, Algonquin, Atikamekw and Innu) to assert their rights on the same land, regardless of the strength of their claim. It is a matter that, as Benoit Ethier, Christian Coocoo and Gerald Ottawa point out in their contribution, some Indigenous communities are trying to resolve through legal action in Canadian courts.

Similarly, as Brian Thom indicates, Indigenous communities that have a recognised settlement area based on a prior treaty may seek to use it at will, notwithstanding that doing so impinges on communities that have intimate connections with these lands but do not yet have agreements. This again ignores the existence 
of a well-developed Indigenous system to regulate land use among kin, community relations and strangers - a fact that fortunately was recognised by the courts in British Columbia. However, as Thom suggests, this is not good enough. Indeed, such court interventions might not be needed were Indigenous communities to regain the authority to regulate relations under their own laws.

For these reasons, I believe that the term overlap should be abandoned, as it is a poor descriptor for what is happening. I do not know the best term to use, but perhaps border making is better. However, I can say this: when looked at from the point of view of the state's intent, the goal is more akin to that of ethnic cleansing than mere overlap. That is, the state seeks to transform the polities of peoples previously tied to one another and the land through rich networks of relationality into members of territorial isolates, who in turn are forced by this circumstance to seek the exclusion of all those who stand outside by severing these ties.

\section{Debt Obligations}

Another issue to which I will draw attention is the debt incurred to participate in negotiations. As shown in the articles, negotiations are a long and very expensive process that only begins with the need to establish standing by use of historical data, as well as detailed land use and occupancy studies undertaken by experts (often in conjunction with Indigenous Peoples). Following is the period of actual negotiations, which takes years, if not decades, and hopefully leads first to a preliminary and then a final agreement. In addition to finding negotiators from one's community, one may also have to hire outside negotiators as well as retain legal counsel, obtain expert assistance - perhaps including political advisers - and allocate funds to ensure that the community and its leadership remain informed. Of course, virtually no Indigenous community already has the financial resources to mount such an effort, and so the government of Canada offers loans, which are to be paid when negotiations are completed or when they break down. Consequently, discharging the debt requires the success of negotiations, and, as Ethier and colleagues mention, the Canadian state has not been averse to using threats to withhold funds or calling in debts to force communities to reach agreements on its terms. However, it now seems that, at least on this matter, the federal government has changed its policy, in that the 2019 budget has provisions for cancelling all such debts. At the same time, as Ethier and colleagues describe, debts have yet to be discharged as the commitment is only to do so over time.

\section{Capitalism}

Finally, I need to bring forward the observation contained in Scott's sweeping discussion of the history of the James Bay Agreement and its aftermath. In addition to the need to focus on radical ways to transform relations between Indigenous Peoples and the state, Indigenous Peoples within (and also outside) agreements need to work to counter the effects of "capitalist relations and the premises of indefinite economic growth embodied in state policy" on their lives. This is a matter of great significance that is certainly too broad to address here. However, I wish to note that it is a matter I sought to address when working with the Dene on their negotiations by asking that they consider how relations of production relied upon in the bush might be adapted for use in nonbush settings, such as running an oil rig.

\section{The Objective of Federal Policy, Then and Now}

As the above indicates, federal policy imposes significant limits on the kind of settlement possible. To me, it seems these constraints have been driven over the past 40 years and more by two principle objectives. The first, achieved through the cede-and-surrender clause, is to produce by any means possible an agreement wherein Indigenous Peoples "voluntarily" accept that Canada has ultimate sovereignty and jurisdiction over them. The second, which derives from the border-making demand, is more subtle. In fine, as I see it, the goal is to create conditions that require Indigenous Peoples to replace a polity based on fluid networks of relationality with one based on rigidly defined micro-territories that have every potential to transform a peaceful regime based on mutuality to one based on competition and inter-group hostility.

The fact that the objectives have not changed does not mean that things have remained the same. Far from it. In the 1970s, when Canada first articulated its negotiation's policy, it was a hopeful sign. The reason is that, notwithstanding its harsh terms, it replaced a policy in which it was presumed that either Indigenous rights did not exist or, if they did, they were in fact keeping these communities "backward" and that the solution, as recounted in the 1969 White Paper, was for Canada to rid itself of the Indigenous fact through policies encouraging their rapid assimilation into the body politic.

This turnaround, as is well understood, resulted from pressure from Indigenous communities and others, as well as a series of court judgments and the findings of the Mackenzie Valley Pipeline Commission. So it was a moment of hope when change seemed to be on the way. And this was sustained for at least another two decades 
as, through political pressure, reasoned arguments and court judgments, Indigenous Peoples seemed to be making great strides to gain the kind of recognition they sought. Indeed, for many of us, the inclusion of Aboriginal and Treaty Rights in the 1982 Constitution seemed emblematic of what was to come.

Things have moved significantly - rhetorically and ideologically. Certainly, the words Canada chooses to describe relationships with Indigenous Peoples today bear nothing in common with those used in the 1970s. Nevertheless, as the articles in this thematic section show, things never moved significantly on the ground. Regardless of the words chosen, actions remain as they were in the 1970s. In this regard, I recall the words of advice proffered to the Dene by one of the federal negotiators in our first negotiating session, words that are as relevant now as they were then: "If you want to make a deal, you must break an egg." As we were to understand it, the negotiator was telling us, "We have our position. It will not change. Therefore, if you are ever to reach an agreement with us, you will need to let go of what is most dear to you."

The difference is that, as Colin Scott points out, after all these years, attitudes toward negotiating with the state (or indeed working with it at all) on these terms have hardened among many Indigenous Peoples and activist settlers. They, like Aaron Mills, who is mentioned in Scott's article, take the view that radical transformation is required.

So, my question is this: Where do we go from here?

\section{Future Contributions}

As the contributions from this thematic section show, as anthropologists, we are professionals who use our technical skills ethically in support of Indigenous Peoples seeking to resolve relations with Canada through negotiations. Notwithstanding the pessimistic findings I have discussed in these concluding remarks, I am not advocating that we collectively withdraw from this kind of work (at least not yet). It is important to offer our expertise in the ways described in these essays and others. Nevertheless, other work remains to be done.

The articles in this thematic section show that we are more than technicians; something is lying underneath the discourse. To me, it is that, whether drawn in by circumstances or through inclination, by doing this work, we end up entangled in an existential struggle that permeates the process wherever and whenever it happens. Moreover, in fact, for me, as perhaps for many others (Indigenous leaders included), that load eventually becomes overwhelming and one needs to retreat. I certainly began to feel this way when, after over a decade of negotiations, the federal minister had the nerve to tell the Dene leadership that (to paraphrase) "the airplane is on the runway and the engine is running; if you do not come to an agreement today, I will cancel negotiations (and of course you will be left with an enormous debt)." I remember asking myself: "What is it about settler culture that would allow us to put anyone in that position?" Moreover, following from it, "What can I do to help change it?" Seeking answers to these questions has driven my work ever since.

My path has been to use my training as an anthropologist both to challenge the self-confidence of the state's presumption to have legitimate claims to sovereignty and jurisdiction by focusing on the violent origin story that presumes we discovered an unpeopled land and to offer in my own way the possibility of a radically different manner of doing politics with Indigenous Peoples through treaty relations based largely on what I have come to learn about Indigenous political relationality understandings expressed so clearly in these essays and in other writings. I hope now, as I did earlier in my career, that addressing such matters in these ways will help to move public discourse to reject the approach taken in government policy, as well as offer comfort to those who, fed up with the existing process, now seek solutions through processes that lie outside of the negotiation's structure.

I realise that many others are undertaking this kind of work. However, I believe that as an anthropologist with experience in negotiations, I (as many of you) have a unique perspective to offer based on on-the-ground witnessing of what has been taking place. This includes the ability to report in detail first-hand on how government acts, on the courage of the continued resistance to its agenda and on the hope offered to us all through relational ways of organising politically as we all face the exigencies of living within state structures today. These are matters I see reflected so clearly in these articles, and I hope will see exploration in future contributions by these authors and others. Moreover, for bringing these matters so clearly to our attention here within a set of articles so rich in their discussions of what is transpiring in this arena, I thank the contributors most deeply.

Michael Asch, Department of Anthropology, University of Victoria, Victoria, British Columbia, Canada.Email:masch@uvic.ca.

\section{Notes}

1 In that capacity, I was responsible for supervising all research related to negotiations, as well as working on negotiating 
strategy on matters such as potential overlaps with Inuvialuit and Inuit, preparing position papers on economic development and political relations, and supervising the organisation and digitisation of historical and contemporary land use and occupancy for roughly 450,000 square miles (over one million square kilometres) of lands.
2 My translation; the original phrase in French text is as follows: "Le Traité à intervenir entre les Premières Nations impliquées dans le Regroupement Petapan serait le premier Traité au Canada établi sur la base de reconnaissance des droits plutôt que l'extinction et/ou l'abandon des droits." 